\title{
ELEMENTY TEOLOGII DUCHOWOŚCI W „COLLECTANEA THEOLOGICA” 1920-2020
}

Sięgając do idei przewodniej założycieli stuletniego pisma teologicznego, które ma swój początek we Lwowie, znajdujemy niezwykle sugestywne stwierdzenie w kontekście odzyskania niepodległości przez Polskę. Komitet redakcyjny, we wprowadzeniu do pierwszej publikacji (1920 r.), stwierdza: „Dzisiaj ukazuje się ono w wolnej Polsce, by zapełnić tę lukę, którą odczuwa i ogół duchowieństwa i księża, chcący pracować naukowo, a nie mający gdzie swych prac umieszczać". ${ }^{1}$ Oznacza to, że wraz z odzyskaniem niepodległości Polska miała zasoby intelektualne w zakresie dziedzin teologicznych. Należy jednocześnie zaznaczyć, że, inicjując profesjonalne pismo teologiczne, jego twórcy pragną wpisać się w ogólnoteologiczny dorobek Kościoła. Świadczy o tym stwierdzenie: „Chcielibyśmy nawiązać do wielkich tradycji Długosza, Kromera, Hozjusza, Sokołowskiego i innych, chcielibyśmy, by udział nasz w ogólnopolskim dorobku na polu teologii odpowiadał naszej liczbie i naszym zdolnościom. Dotychczas spotykamy tam przeważnie imiona włoskie, francuskie, niemieckie, hiszpańskie i belgijskie. Czas najwyższy, by znalazły się tam i nazwiska polskie!".

Jak możemy zauważyć, analizując początki powstawania periodyku, zawiera on dość szerokie spectrum poruszanych problemów. Pośród nich, od samego początku, zaznacza swoją obecność teologia duchowości, która, jak stwierdza ks. prof. M. Chmielewski, jako PT).

Komitet redakcyjny, Nasz program, Przegląd Teologiczny 1/1920, s. 1 (dalej:

Tamże. 
dyscyplina akademicka pojawiła się dopiero na początku XX w. ${ }^{3}$ Należy podkreślić, że Stolica Apostolska uznała odrębność ascetyki w stosunku do innych kierunków teologii. Opierając się na konstytucji apostolskiej papieża Piusa XI Deus scientiarum Dominus, wydanej w 1931 r., a dotyczącej uniwersytetów i wydziałów kościelnych, ascetykę włączono do studiów jako odrębny przedmiot teologii. ${ }^{4}$ Wówczas funkcjonowało określenie ,ascetyka”, ale w odrębności od teologii moralnej. Z punktu widzenia podejmowanych badań podkreślenie tego aspektu jest konieczne, ponieważ w sposób bezpośredni rzutuje na charakter badanego materiału.

Sięgając jednak do badań nad tym kierunkiem refleksji teologicznej, stwierdzamy, że faktycznie istniała ona od początków Kościoła, ze szczególnym podkreśleniem znaczenia okresu patrystycznego, a także sukcesywnie rozwijających się kierunków związanych z powstawaniem zakonów oraz szkół duchowości. W tradycji teologicznej Kościoła istniała jako pewien, niezależny od badań uniwersyteckich, nurt ascetyczno-mistyczny. Jak możemy zauważyć, inicjacja „Przeglądu Teologicznego" organicznie łączy się z formalnym początkiem teologii duchowości jako odrębnego kierunku naukowo-badawczego w Kościele. W kontekście przeżywania ,jubileuszu” tegoż czasopisma niezwykle istotne jest dokonanie pewnej analizy publikacji, które ono zawiera, i które dotyczą właśnie tej teologii.

3 M. Chmielewski, Teologia duchowości, w: tenże (red.), Leksykon duchowości katolickiej, Lublin-Kraków 2002, s. 878. Należy stwierdzić, że samo pojęcie duchowości ma dość szerokie znaczenie. Zawężając je do duchowości chrześcijańskiej, mamy do czynienia z jej podwójnym wymiarem, tj. 1. życie duchowe człowieka, które koncentruje się na jego praktykowaniu, zwana niekiedy przeżyciową (sens subiektywny); 2. refleksja naukowo-badawcza, która zajmuje się badaniem źródła życia duchowego, jego procesem (próba wyznaczenia etapów rozwoju człowieka) oraz środkami tegoż rozwoju (sens obiektywny). W drugim przypadku mamy do czynienia z teologią życia duchowego. Niekiedy duchowość określana jest mianem akademickiej ze względu na refleksję intelektualną nad doświadczeniem duchowym. Przyjmuje się, że mamy do czynienia z jedną duchowością, która posiada różnorodność dróg oraz form, tamże, s. 226-232.

4 Pius XI, Deus scientiarum Dominus, 24 V 1931, AAS 23/1931, s. 241-284. 


\section{Ogólna charakterystyka publikacji}

Analiza okresu stu lat ukazywania się pisma teologicznego musi uwzględniać zachodzące zmiany, które dokonały się w życiu świata, Kościoła a także uprawiania teologii. Jak stwierdza ks. prof. J. Misiurek: „Wiek [XX - przyp. M.T.], który przeszedł już do historii, obfitował w najrozmaitsze wydarzenia w naszej Ojczyźnie: odzyskanie niepodległości w 1918 r., a potem nowa niewola i okupacja hitlerowska, następnie okres zniewolenia komunistycznego i dalsze próby odchodzenia od systemu rządów totalitarnych, zwłaszcza po 1989 r."5 Oczywiście te wszystkie wydarzenia znalazły swoje odzwierciedlenie zarówno w życiu Kościoła, jak i rozwoju teologii w ogóle, a także teologii duchowości. Odsłania się w tej korelacji pewna „wrażliwość” duchowości, która pozostawiła zarówno dorobek teologiczny, jak również wybitne osobowości i z tego względu możemy mówić o uformowaniu się „polskiej szkoły duchowości”6 a także o ,złotym okresie rodzimej mistyki". ${ }^{7} \mathrm{~W}$ pewnym stopniu znalazły one odzwierciedlenie w „Przeglądzie Teologicznym” a następnie w „Collectanea Theologica”, ${ }^{8}$ którego ,życie” rozpoczęło się we Lwowie będącym, obok Krakowa, Wilna oraz Warszawy, istotnym ośrodkiem rozwoju polskiej myśli teologicznej. Nie bez znaczenia dla rozwoju pisma pozostaje wydarzenie z 1 stycznia 1934 r., kiedy to przeszło ono na własność Polskiego Towarzystwa Teologicznego z zaznaczeniem, że przybiera ukierunkowanie „wschodnie” ze względu na takie potrzeby. ${ }^{9}$ Równie istotnym, a jednocześnie dramatycznym wydarzeniem, które spowodowało swoistą ,lukę" w procesie rozwoju myśli teologicznej jest okres II wojny światowej. Jak można zauważyć, spowodował on przerwę trwającą od 1939 aż do 1949 r.

5 J. Misiurek, Historia i teologia polskiej duchowości katolickiej, t. III: W. XX, Lublin 2001, s. 5.

6 S. Urbański, Polska szkoła duchowości, Warszawa 2016, s. 9.

7 Tenże, Duchowość polska, Warszawa 2002, s. 7.

8 Zmiana tytułu czasopisma nastąpiła wraz z wydaniem Collectanea Theologica 13/1931 (dalej: CT).

9 CT 15/ 1934. 
Jednocześnie, jak to zostanie dalej wyeksponowane, stał się motywem wielu analiz i opracowań, także na gruncie teologii duchowości. Bez wątpienia wybitną inspiracją rozwoju był II Sobór Watykański, który otworzył nową jakość Kościoła. Podkreślając powszechne powołanie do świętości, ${ }^{10}$ stworzył nowe przestrzenie do rozwoju duchowości. Do tych kluczowych impulsów należy także wybór oraz pontyfikat Jana Pawła II. Analiza publikacji pozwala stwierdzić, że zwrócono przede wszystkim uwagę na treści nauczania zawarte w encyklikach, adhortacjach, listach, homiliach czy też rozważaniach. Wszystkie te akcenty zostaną przywołane w analizie poszczególnych kierunków rozwoju duchowości, które wyłaniają się z publikacji w tymże czasopiśmie teologicznym.

Kwerenda stuletniego czasopisma pod kątem teologii duchowości pozwala zauważyć, że mamy do czynienia z bardzo bogatymi i niezwykle zróżnicowanymi zasobami tekstów. Jest ich sto dwadzieścia cztery. Kwalifikacja oraz rozeznanie zostało przeprowadzone z punktu widzenia teologii duchowości. Oznacza to, że autorami nie zawsze są teologowie duchowości. Przede wszystkim należy mieć na uwadze, że mimo swoistego ,wyzwolenia” ten rodzaj uprawianej teologii ciągle pozostawał w ścisłej łączności z teologią moralną bądź dogmatyczną. Warto zauważyć, że w Polsce jej początki związane są z wybitną postacią, którą był rektor KUL, ks. prof. A. Słomkowski (1944-1951). To z jego inicjatywy w 1957 r. powołano pierwszą w Polsce akademicką Katedrę Teologii Ascetycznej i Mistycznej przy Sekcji Teologii Dogmatycznej na ówczesnym Wydziale Teologicznym KUL-u. Z kolei absolwent KUL, ks. prof. Stanisław Urbański, który na tymże uniwersytecie studiował teologię pastoralną, a następnie w latach 1974-1979 teologię duchowości i teologię moralną, w 1979 r. obronił pierwszy w Polsce doktorat z teologii duchowości. ${ }^{11}$ Przywołanie tego autorytetu jest niezwykle istotne. Inicjatorem odrębności teologii duchowości w postaci dwóch katedr (Teologii Życia We-

10 KK 39.

11 W. Gałązka, Curriculum vitae, w: W. Gałązka, P. Latawiec, H. Podolski, K. Trawkowski (red.), Servire Deo et hominibus, Warszawa 2009, s. 15. 
wnętrznego oraz Hagiografii) w ATK był ks. prof. S. Olejnik. Katedry te były one włączone w Sekcję Teologii Moralnej. Po pozytywnym przewodzie habilitacyjnym ks. S. Urbański w 1989 r. zorganizował na Wydziale Teologicznym ATK Sekcję Teologii Duchowości. Wątek ten jest ważny, ponieważ dotyczy pisma teologicznego związanego organicznie z ATK/UKSW. Otwartość poszczególnych komitetów redakcyjnych czasopisma sprawiała i sprawia, że teksty dotyczące duchowości są publikowane przez wielu autorów z różnych dziedzin teologii. Nie bez znaczenia pozostają dla rozwoju tejże dziedziny teologicznej inne ośrodki teologiczne w Polsce, np. Kraków, Wrocław, Toruń, Poznań, Szczecin, które mają bardzo istotny wpływ na kształtowanie się tego kierunku teologicznego.

Bez wątpienia na pierwszym miejscu należy postawić ściśle naukowe artykuły, podejmujące istotne zagadnienia i problemy z zakresu teologii duchowości. Jednak mamy także do czynienia z publikacjami o charakterze interdyscyplinarnym na gruncie teologii. W szerokim znaczeniu zostały one także zakwalifikowane i potraktowane jako opracowania z zakresu teologii duchowości ze względu na jej elementy. Obok tego w poszczególnych tomach periodyku znajdujemy recenzje dzieł naukowych i opracowań rodzimych oraz zagranicznych z tego kierunku teologicznego. Oznacza to niezwykle cenną i istotną otwartość w przestrzeni naukowo-badawczej. Trzecią kategorią są sprawozdania dotyczące kongresów, sympozjów czy spotkań teologów. To także bardzo bogaty materiał badawczy, ponieważ odsłania sposób rozwijania się teologii duchowości w Polsce, a także sposób kształtowania myśli teologicznej. Opracowanie i analiza tak bogatego i jednocześnie pod wieloma względami zróżnicowanego materiału domagały się zastosowania właściwych kryteriów podziału. Z tego względu w prowadzonej kwerendzie należało uwzględnić szerokie spojrzenie na duchowość. To pozwala wyodrębnić poszczególne kierunki publikacji. W opracowaniu przyjęta została zasada ilościowa a następnie jakościowa co do opracowań i na tej podstawie dokonano kwalifikacji. Ich treść a także zawartość w pewien sposób odzwierciedlają owe tendencje teologiczne w Polsce i reakcje na wydarzenia 
w życiu Kościoła i świata, ale także są dowodem niepozostawania teologii duchowości w Polsce w przestrzeni ekskluzywnej.

\section{Historia duchowości}

Ten kierunek badań jest niezwykle istotny dla duchowości i można powiedzieć, że jest z nią związany w sposób organiczny. Dotyka historycznego wymiaru doświadczenia jedności Boga i człowieka. Oznacza to, że historia człowieka i cywilizacji, którą buduje on w świecie, wpisuje się w cały opatrznościowy plan Boga. Praca naukowo-badawcza tego kierunku duchowości chrześcijańskiej, współpracując z innymi dziedzinami teologicznymi oraz poza teologicznymi, odsłania doświadczenia objawiania się Boga Trójjedynego człowiekowi. Znalazło ono pełne odzwierciedlenie w Osobie Jezusa Chrystusa. Historia duchowości obejmuje swoimi badaniami bardzo szerokie spectrum, począwszy od Kościoła wschodniego, zachodniego, a także nurty takie jak: laikat, zakony męskie i żeńskie, szkoły duchowości. ${ }^{12}$

Sięgając do opracowań zawartych w „Przeglądzie Teologicznym” oraz „Collectanea Theologica”, znajdujemy pełne odzwierciedlenie tych tendencji i kierunków. Są one w dużej mierze odpowiedzią na wydarzenia historyczne i społeczne. Wśród publikacji „Przeglądu Teologicznego", zaraz po zakończeniu I wojny światowej oraz odzyskaniu przez Polskę niepodległości, możemy znaleźć odniesienie do teologii narodu oraz jego duchowości w opracowaniu ks. A. Mocko. ${ }^{13}$ W tym kontekście ks. K. Wajs podjął się opracowania zagrożeń, które wynikają z tendencji magicznych, okultystycznych, mediumistycznych i spirytystycznych po utracie najbliższych w wyniku działań wojennych. ${ }^{14}$

12 J. A. Wiseman, Historia duchowości chrześcijańskiej, tłum. A. Wojtasik, Kraków 2009, s. 11-15.

13 A. Mocko, Teologia w „Dziadach” Mickiewicza, PT 1(1920) nr 3-4, s. 216-233.

14 K. Wajs, Spirytyzm, PT 1(1920) nr 2, s. 82-113. 
Do opracowań o charakterze historycznym należy bez wątpienia publikacja ks. J. Noryśkiewicza. Autor podjął się bardzo bogatego zaprezentowania historii życia zakonnego w latach $1772-1840 .{ }^{15}$ Podobnie historyczno-duchowościowe omówienie zawiera publikacja ks. K. Kantaka. ${ }^{16} \mathrm{~W}$ tej kategorii mieści się również bardzo cenne opracowanie ks. W. Kłapkowskiego ${ }^{17}$ a także ks. J. Kładocznego, który, zgodnie z przyjętą przez redaktorów pisma tezą, zajmuje się duchowością chrześcijańskiego Wschodu. Dotyka przede wszystkim problemu kasaty zakonów przez władze carskie po $1863 \mathrm{r}$. Wprawdzie dotyczyła ona głównie klasztorów katolickich, ale, jak wykazuje autor, znalazła zastosowanie także wobec bazylianów. ${ }^{18}$

Wśród opracowań historycznych swoje miejsce odnalazły również diecezjalne seminaria duchowne. Problem ich istnienia, roli a także formacji podjął ks. T. Długosz. ${ }^{19}$

Oprócz analizy historycznej, której przedmiotem są wydarzenia z życia Kościoła czy też zakonów, wśród publikacji w tymże teologicznym periodyku odnajdujemy opracowania dotyczące historycznych aspektów praktyk życia chrześcijańskiego. Do nich należą teksty ks. A. Kraśnickiego, który prezentuje bardzo szeroką analizę dotyczącą praktyk postu, jego charakteru, znaczenia dla życia chrześcijańskiego, jak również praktyk w szczególne okresy i dni. To opracowanie obejmuje okres w Polsce od początku XV w. do rozbiorów. ${ }^{20}$

Charakter przeżywanej duchowości związany jest z miejscami, ośrodkami czy też centrami. Są one nieodłączne od osób, które są

15 J. Noryśkiewicz, Sekularyzacja klasztorów w Wielkopolsce przez rząd pruski, PT 6(1925) nr 3, s. 240-282.

16 K. Kantak, Życie wewnętrzne bernardynów $w$ dobie poreformacyjnej, PT 10(1929) nr 3, s. 315-352.

17 W. Kłapkowski, Pierwsze dwa przywileje karmelitów trzewiczkowych klasztoru Bożego Ciała w Poznaniu, CT 13/1932, s. 241-247.

18 J. Kładoczny, Ostatnie chwile prowincji bazyliańskiej w Królestwie Polskim, CT 15/1934, s. 93-103.

19 T. Długosz, Seminaria duchowne we wschodniej Polsce do 1800 r., CT 16(1935) nr 4, s. 23-37.

20 A. Kraśnicki, Posty w dawnej Polsce, CT 13/1931, s. 190-235, 299-382. 
z nimi związane. Z tego względu pośród publikacji znajduje się opracowanie dotyczące sanktuarium w Trzebnicy, życia i pracy cystersów a także zabytków pozostałych po św. Jadwidze. ${ }^{21}$

\section{Hagiografia}

Jak wynika ze studium nad teologią duchowości chrześcijańskiej, hagiografia stanowi bardzo istotny jej element. Szczególnie uwidacznia się ona w duchowości Kościoła katolickiego oraz Kościołów wschodnich niekatolickich. Określając ją w szerokim znaczeniu, należy stwierdzić, że dotyczy świętych. Uszczegóławiając zaś, twierdzi się, że obejmuje piśmiennictwo mówiące o świętych i ich życiu oraz kulcie. W przestrzeni teologicznej jest analizą i krytycznym studium nad źródłami, przy zastosowaniu metod historycznych, psychologicznych oraz teologicznych. ${ }^{22}$ Święci, ich życiorysy a także spuścizna duchowa oraz intelektualna, byli od początku Kościoła źródłem inspirującym do życia duchowego, a także do naukowo-badawczego opracowania ich duchowości. Jest to zatem kategoria duchowości ukonkretnionej w życiu, doświadczeniu oraz nauczaniu człowieka dążącego do zjednoczenia z Bogiem. W wielu przypadkach byli to założyciele, fundatorzy oraz inicjatorzy określonej drogi uświęcającej czy też modelu życia zakonnego, kapłańskiego, małżeńskiego bądź samotnego. Możemy zatem stwierdzić, że hagiografia odsłania dwa rodzaje duchowości, tj. przeżyciową oraz naukowo-akademicką.

Analiza publikacji w stuletnim okresie istnienia „Przeglądu Teologicznego" oraz „Collectanea Theologica” prowadzi nas do wniosku, że ten charakter hagiografii został nie tylko w pełni zachowany, a wręcz bardzo owocnie rozwinięty. Pierwszym ze świętych, który doczekał się opracowania, jest Franciszek z Asyżu w analizie porównawczej z Janem z Komorowa, o. Prokopem Leszczyńskim,

21 T. Kruszyński, Święta Jadwiga Śląska i jej sanktuarium w Trzebnicy, CT 28(1957) nr 3-4, s. 598-705.

22 I. Werbiński, Hagiografia, w: M. Chmielewski (red.), Leksykon duchowości katolickiej, s. 307. 
Edwardem Porębowiczem, br. Honoratem Kapucynem oraz o. Euzebiuszem Statecznym. Dzieła tego dokonał tego ks. B. Gładysz. ${ }^{23}$ Kolejnym świętym, który znalazł swoje miejsce w periodyku, był św. Antoni. ${ }^{24}$ Ksiądz. K. Wilk dokonał zestawienia oraz usystematyzowania dostępnej literatury na temat tego świętego. ${ }^{25}$ Tendencje i próby umiędzynarodowienia $\mathrm{w}$ tej dziedzinie potwierdza opracowanie dotyczące Giuseppe Alamano (1851-1926), założyciela męskiego i żeńskiego zgromadzenia misyjnego (Instituto Missioni Consolata), którego dokonał Divo Barsotti. ${ }^{26}$ Pośród opracowań wybitnych postaci znajduje się także Thomas More (1478-1535), kanclerz Henryka VIII, wybitny polityk oraz męczennik, ${ }^{27}$ a także Teresa de los Andes (Juanita Fernandez Solar). Nad jej osobą pochylił się ks. J. Hadryś, wydobywając rys biograficzny oraz nakreślając jej drogę duchową. ${ }^{28}$

Jako pierwszy z polskich teologów swoje hagiograficzne opracowanie ma Mikołaj z Mościsk. ${ }^{29}$ Następną osobą, która znalazła swe miejsce na łamach tego pisma teologicznego, była s. Urszula Ledóchowska. Opracowanie to jest owocem jej beatyfikacji przez Jana Pawła II. ${ }^{30}$

Jak możemy zatem zauważyć, w sposób zdecydowany przeważają opracowania dotyczące postaci spoza Polski. Z pewnością świadczy to o otwarciu na przestrzenie teologiczne całego Kościoła, jednakże można zauważyć pewien niedosyt $\mathrm{w}$ tej dziedzinie.

${ }^{23}$ B. Gładysz, Św. Franciszek z Asyżu w hagiografii polskiej, PT 7/1926, s. $337-368$.

${ }^{24}$ K. Wilk, Żywot św. Antoniego z Padwy, PT 9/1928, s. 147-158, 281-299.

25 Tenże, Literatura o św. Antonim Padewskim od XV do XX wieku, CT 11/1931, s. $75-98$

26 D. Barsotti, Prymat świętości, CT 51(1981) nr 1, s. 163-184.

27 G. Antoniuk, Duchowość Tomasza More'a, CT 58(1988) nr 1, s. 112-120.

28 J. Hadryś, Życie modlitewne Teresy z los Andes w świetle jej Dziennika i Listów, CT 78(2008) nr. 1, s. 31-49.

29 W. Wicher, Mikołaj z Mościsk teolog-moralista i pisarz ascetyczny, PT 9/1928, s. 209-225.

30 J. Bakalarz, M. Urszula Ledóchowska jako opiekunka polskich emigrantów, CT 54(1984) nr 2, s. 175-180. 


\section{Duchowość patrystyczna}

Najwłaściwszymi i najpełniejszymi podstawami teologii duchowości chrześcijańskiej jest słowo Boże. Jednak początek Kościoła i realizacja misji powierzonej każdemu, kto do niego przynależy, to okres patrystyczny. To wówczas rodziły się postawy radykalnego pójścia za Chrystusem wraz z męczeńskim oddaniem życia. W tym okresie także kształtowały się pierwsze formuły wyznania wiary oraz określenia zasadniczych dogmatów. $\mathrm{Z}$ tego względu teologia nie może nie uwzględniać dziedzictwa patrystycznego oraz patrologicznego. Jest ono równie ważne do kształtowania się duchowości chrześcijańskiej, zarówno przeżyciowej, jak i spekulatywnej. ${ }^{31}$

Sięgając do opracowań, które zostały opublikowane w „Przeglądzie Teologicznym” oraz „Collectanea Theologica”, możemy stwierdzić, że są one wieloaspektowe oraz wielokierunkowe. Publikacje te podejmują zasadnicze elementy duchowości chrześcijańskiej w ujęciu najbardziej transparentnych ojców Kościoła.

Już w pierwszym egzemplarzu "Przeglądu Teologicznego" z 1920 r. ks. A. Mocko odwołuje się do św. Augustyna, prezentując takie elementy duchowości, jak: obcowanie świętych, modlitwa oraz zadośćuczynienie. ${ }^{32}$ Jak można zauważyć, analizując publikacje, bardzo istotne miejsce zajmuje w nich patrystyczna duchowość sakramentalna. Ksiądz W. Kamczyk, opierając się na tekstach Marka Eremity, nakreślił problem grzechu Adama, sakramentalności chrztu i jego znaczenia dla życia pod wpływem Ducha Świętego. ${ }^{33}$ Sięgając do nauczania św. Ignacego Antiocheńskiego, B. Jankowski ukazał znaczenie i rolę Eucharystii w życiu i rozwoju wiary chrześcijanina. ${ }^{34}$ $\mathrm{Z}$ kolei ks. prof. M. Sieniatycki w trzech obszernych artykułach doko-

31 Ch. J. Healey, Christian Spirituality. An Introduction to the Heritage, New York1998, s. 1; J. A. Wiseman, Historia duchowości chrześcijańskiej, s. 125-126.

32 A. Mocko, Teologia w „Dziadach” Mickiewicza, PT 1(1920) nr 1, s. 17-18.

33 W. Kamczyk, Duchowe i moralne implikacje chrztu wedtug Marka Eremity, CT 89( 2019) nr 1, s. 15-32.

34 B. Jankowski, De Eucharistia apud Ignatium Antiocheum, CT 22(1951-1952) nr 1-4, s. 42-76. 
nał analizy pokuty w ujęciu ojców zachodnich: 1. Sakrament pokuty, karcenie penitenta, ekskomunika; 2. Pokuta publiczna, zadośćuczynienie, pokuta tajna; 3. Grzech, spowiedź publiczna, rozgrzeszenie i komunia św. ${ }^{35}$ Duchowością patrystyczną, dotyczącą sakramentu kapłaństwa, zajął się ks. L. Wasilkowski, opracowując ujęcie św. Cypriana. Wykazując istotę i naturę tego sakramentu, z wielkim powodzeniem podjął polemikę z protestantyzmem i racjonalizmem Behma, odwołując się również do poglądów Otto Ritschla, Sohma, Poschmanna, Brudersa, Leclerca, Halliera, Wetzego. ${ }^{36}$

W tym czasie podejmowane były zagadnienia, które dotyczą duchowości eklezjalnej. Autorami są ks. M. Sieniatycki ${ }^{37}$ oraz ks. dr J. Czuj, który opierając się na św. Augustynie, polemizuje z protestantyzmem i jego przedstawicielem Reuterem. ${ }^{38}$ Kontynuatorem myśli dotyczącej tej kategorii duchowości jest ks. J. Grzywaczewski, prezentując koncepcję eklezjalno-sakramentalną u Marka Eremity. ${ }^{39}$

Zagadnienie antropologii a także wymiaru psychologicznego jest niezwykle istotne dla teologii duchowości chrześcijańskiej. Z tego względu, podejmując analizę od strony psychologiczno-antropologicznej oraz teologicznej, ks. J. Pastuszka podjął refleksję dotyczącą duszy człowieka w ujęciu św. Augustyna. ${ }^{40}$ Elementy istotne dla

35 M. Sieniatycki, Pokuta kościelna wedtug Ojców zachodnich PT 2(1921) nr 1, s. 33 -39; PT 2(1921) nr 2, s. 147-160; PT 2(1921) nr 3-4, s. 213-236; tenże, Spory na Zachodzie o dyscyplinę pokutna, PT 3(1922) nr 4, s. 273-301.

36 L. Wasilkowski, Nauka św. Cypriana z Kartaginy o kapłaństwie w zestawieniu z tradycją pierwszych trzech wieków, PT 4(1923) nr 1, s. 4-33; PT 4(1923) nr 2, s. 140-154.

37 M. Sieniatycki, Nauka Ojców apostolskich o Kościele, PT 3(1922) nr 1, s. 31-56.

38 J. Czuj, Idea biskupstwa uśw. Augustyna, PT 2(1921) nr 3-4, s. 237-245; tenże, Kościół u św. Augustyna, PT 4(1923) nr 3, s. 281-298.

39 J. Grzywaczewski, Zagadnienie Kościoła w kontekście ascetycznym Marka Eremity, CT 89(2019) nr 1, s. 51-73.

40 J. Pastuszka, Pojęcie duszy ludzkiej u św. Augustyna, PT 10/1929, s. 389-406. 
duchowości w tym względzie znalazły także swoje miejsce w opracowaniu ks. Z. Burgielskiego. ${ }^{41}$

W opracowaniach „Collectanea Theologica” mamy do czynienia z mocnym oddźwiękiem analiz dotyczących teologii i duchowości męczeństwa. Jak zostało wspomniane, w okresie patrystycznym miało ono dość kluczowe znaczenie. $\mathrm{Z}$ tego względu męczennicy przedstawiani są w Kościele jako wzór wierności Chrystusowi i szczyt dojrzałości chrześcijańskiej. ${ }^{42}$ Równie inspirujące jest nakreślenie relacji między męczeństwem pierwszych wieków chrześcijaństwa a tragizmem obozów koncentracyjnych, którego podjął się ks. A. Kubiś. Można zauważyć, że jest to ciągła reminiscencja tragicznych doświadczeń związanych z II wojną światową, upadkiem człowieka a jednocześnie jego heroizmem, np. postawa św. Maksymiliana Kolbego - męczennika. ${ }^{43}$

Obok ideału męczeństwa, jak zauważają autorzy, idąc za teologią ojców Kościoła, dążenie do zjednoczenia z Chrystusem dokonuje się na drodze rozwoju procesu uświęcającego. Właśnie ten aspekt wyodrębnił ks. J. M. Szymusiak, podkreślając znaczenie ideału, obowiązków „dusz poświęconych”, rolę światłości Bożej i wewnętrznej wolności człowieka. ${ }^{44}$ Kontynuatorem tej myśli był ks. I. Werbiński, który podjął analizę nad uaktualnieniem charyzmatu eremickiego w czasach współczesnych. ${ }^{45}$ Jednym $\mathrm{z}$ tych ideałów jest dziewictwo konsekrowane, ciągle aktualne w życiu Kościoła a mające swój

${ }_{41}$ Z. Burgielski, Nieśmiertelność duszy ludzkiej w świetle nauki św. Augustyna, CT 20/1939, s. 121-198.

42 R. Paciorkowski, Z badań nad idea heroizmu religijnego chrześcijańskiej starożytności, CT 28(195) nr 3-4, s. 503-539.

43 A. Kubiś, Męczeństwo chrześcijańskie a obozy koncentracyjne, CT 41(1971) nr 4, s. 67-73.

44 J. M. Szymusiak, Eremityzm serca. Dążenie do doskonałości wedtug Grzegorza z Nazjanzu, CT 37(1967) nr 1, s. 55-72.

45 I. Werbiński, Potrzeba realizacji charyzmatu eremickiego w czasach wspótczesnych, CT 69(1998) nr 4, s. 55-70. 
pierwowzór w początkach chrześcijaństwa, jak wykazał to P. Libera. ${ }^{46}$ Dynamika tegoż rozwoju w życiu duchowym jest bezpośrednio zależna od rozwoju modlitwy, jak wykazuje É. Escure-Delpeuch, podkreślając jej związek z sercem, walkę o pozbycie się rozproszeń, nieustanność, bliskość z Bogiem a przede wszystkim jej charakter jednoczący z Nim. ${ }^{47}$

Autorzy publikacji, biorąc pod uwagę przeszkody na drodze uświęcającej, sięgali do ogromnego dorobku patrystycznego w tym względzie, np. Z. Goliński, opierając się na nauczaniu św. Kasjana, analizuje problem tzw. kłamstwa użytecznego. ${ }^{48}$

Jak możemy zauważyć, bogactwo opracowań, opierających się na dziedzictwie patrystycznym, wydobywa zasadnicze elementy teologii duchowości chrześcijańskiej jednakże dotyka tylko wybranych przedstawicieli tego okresu.

\section{Teologia duchowości}

Zarówno „Przegląd Teologiczny”, jak również późniejsza „Collectanea Theologica", pretendowały do rangi pisma otwierającego możliwości rozwijania się polskiego środowiska teologicznego. Jak zostało zauważone wyżej, powstanie tegoż periodyku teologicznego niemal zbieżne jest z zaistnieniem teologii duchowości jako odrębnej dziedziny teologicznej. Z tego względu w stuletniej przestrzeni jego rozwoju znajdowały swoje miejsce dogłębne analizy teologiczne w tym zakresie. Przede wszystkim chodziło o to, by nakreślić, czym jest sama teologia duchowości, w jaki sposób rozwija się jako nauka podejmująca badanie zjawiska zjednoczenia z Bogiem a także ukazać jej praktyczne przejawy. ${ }^{49}$ Dotykamy zatem fundamentalnych

46 P. Libera, Duchowość dziewictwa konsekrowanego w świetle pism św. Ambrożego z Mediolanu, CT 64(1994) nr 4, s. 87-100.

47 É. Escure-Delpeuch, Modlitwa wedtug Marka Eremity, CT 89(2019) nr 1, s. $33-50$.

48 Z. Goliński, Nauka Kasjana o kłamstwie użytecznym, CT 17/1936, s. 491-502.

49 P. F. Sheldrake, Explorations in Spirituality. History, Theology, and Social Practice, New York 2010, s. 12-13. 
elementów konstytuujących tę dziedzinę, które z konieczności muszą odwoływać się do wyników pracy naukowo-badawczej w zakresie teologii dogmatycznej. Ojciec A. M. Gmurowski w swoim opracowaniu wykazywał, że duchowy rozwój chrześcijanina jest jego zasadniczym powołaniem. Opierając się na św. Tomaszu z Akwinu, uzasadniał, że powinność ta wynika z podwójnego prawa, tj. miłości Boga oraz racji rozumowych. ${ }^{50} \mathrm{Z}$ kolei ks. Z. Burgielski pokreślił szczególne znaczenie podstaw dogmatycznych dla teologii duchowości, zaznaczając, że o tym ukierunkowaniu człowieka świadczy nieśmiertelność duszy ludzkiej. ${ }^{51}$ Obok tych racji ks. A. Żychliński, który należy do prekursorów polskiej teologii duchowości, wskazywał na wpisaną w naturę człowieka naturalną dążność do zjednoczenia z Bogiem, która spotyka się z nadprzyrodzonym usprawnieniem jego natury na tej drodze. ${ }^{52}$ Jednocześnie jego opracowanie stanowi odpowiedź na niebezpieczne tendencje modernistyczne podejmujące próby wprowadzenia racjonalistycznego redukcjonizmu w życiu człowieka. ${ }^{53}$ Tenże sam autor wykazuje, że fundamentem rozwoju życia duchowego jest łaska uświęcająca. W tym względzie, zgodnie z kanonem uprawianej wówczas teologii, opierał się na mistrzu z Akwinu. ${ }^{54}$ Wątek ten znalazł także swoje odzwierciedlenie w publikacji ks. F. Blachnickiego, który, odnosząc się do antropocentryzmu Arnolda, wskazał na synergizm i odniesienie do porządku natury i łaski. Jego analiza jest wprowadzeniem myśli II Soboru Watykańskiego. ${ }^{55}$ Zaś ks. M. Tatar, niejako kontynuując tę myśl relacji łaski i natury w życiu człowieka,

50 A. M. Gmurowski, Podwójna podstawa obowiązku dążenia do doskonałości, PT 9/1928, s. 167-183.

51 Z. Burgielski, Nieśmiertelność duszy ludzkiej w świetle nauki św. Augustyna, s. $121-198$

52 A. Żychliński, O tak zwanej „Potentia obedientalis”, PT 8(1927) nr 4, s. 378-392.

53 Tenże, O tak zwanej „Potentia obedientalis”, PT 8(1927) nr 3, s. 269-287.

54 A. Żychliński, Nauka Tomasza z Akwinu o naturze łaski działającej, PT 9/1928, s. 347-366.

55 F. Blachnicki, Stosunek natury do łaski jako problem teologiczno-pastoralny, CT 36(1966) nr 1-4, s. 128-156. 
wyakcentował znaczenie nadprzyrodzonej wiary i jej komunikacyjno-komunijne znaczenie w procesie rozwoju życia duchowego chrześcijanina. ${ }^{56}$

Sięgając do dorobku polskiego periodyku w dziedzinie duchowości, należy podkreślić, że u podstaw znajduje się życie sakramentalne. Eucharystia, która jest źródłem życia duchowego, stanowi jednocześnie najgłębsze doświadczenie jedności z Chrystusem. Już w 1928 r. ks. E. Święcicki opublikował dwa artykuły, w których zaprezentował ks. P. Skargę jako obrońcę Eucharystii, w polemice z protestantyzmem, szczególnie w wydaniu kalwińskim, przyjętym przez rody Kiszków, Chodkiewiczów, Sapiehów, Wołłowiczów i Radziwiłłów. Autor w swojej polemice opiera się na dziełach Wolana. ${ }^{57} \mathrm{~W}$ pracach badawczych nad tym niezwykle istotnym aspektem polscy teologowie sięgali do zasadniczego źródła, jakim jest słowo Boże, ale także to pierwszych refleksji teologicznych. Ksiądz B. Jankowski w swoim opracowaniu odwołuje się do początków Kościoła oraz nauczania św. Ignacego Antiocheńskiego. ${ }^{58}$ Niezwykle cennym materiałem w prezentacji duchowości tego sakramentu jest opracowanie pasjonisty, o. J. Kopcia, który zaprezentował materiały sympozjalne dotyczące Eucharystii. Przede wszystkim nakreślił on pojęcie duchowości eucharystycznej, a następnie wykazał, że znajduje się ona w centrum duchowości eklezjalnej, pasyjnej oraz osobistej chrześcijanina. ${ }^{59}$

Obok Eucharystii bardzo mocny akcent w historii pisma dotyczy pokuty. Należy stwierdzić, że podobnie jak Eucharystia należy ona do zasadniczych elementów dynamiki rozwoju życia duchowego chrześcijanina. Właściwie wszystko, czego doświadcza chrześcijanin, ma charakter oczyszczający, czyli prowadzący do zerwania z grzechem i jednocześnie jest zwróceniem się ku Bogu. ${ }^{60}$ Ogromne znaczenie

56 M. Tatar, Komunikacyjno-komunijny wymiar wiary w rozwoju duchowym człowieka, CT 83(2013) nr 1, s. 111-128

57 E. Święcki, Skarga jako obrońca katolickiej nauki o Eucharystii, PT 9/1928, s. 22-38, 226-252.

58 B. Jankowski, De Eucharistia apud Ignatium Antiocheum, s. 42-76.

59 J. J. Kopeć, Duchowość eucharystyczna, CT 67(1997) nr 3, s. 41-59.

60 J. Gogola, Teologia komunii z Bogiem, Kraków 2001, s. 338. 
w kształtowaniu się właściwego rozumienia pokuty odegrały patrystyczne publikacje ks. M. Siemiatyckiego. Ich analiza prowadzi do stwierdzenia, że teologia w tym względzie rozwija się w dwóch kierunkach, tj. sakramentu pokuty a także praktyk pokutnych chrześcijanina. Mamy do czynienia ze znakomitym jego opracowaniem sakramentu w kontekście ekskomuniki, pokuty publicznej, pokuty „tajnej”, zadośćuczynienia, grzechu, spowiedzi publicznej, rozgrzeszenia a także komunii św. ${ }^{61}$ Tematyka ta znalazła swoją kontynuację w publikacji ks. S. Moysy. Jest to ujęcie dość dogmatyczne, ale zawiera elementy, które stanowią znakomitą podstawę dla teologii duchowości. ${ }^{62}$

Zagadnieniem opracowania tego sakramentu od strony szafarza zajął się ks. R. Selejdak. Motywem opracowania było ogłoszenie przez papieża Benedykta XVI Roku Kapłańskiego w Kościele (2009-2010) a także 150. rocznica śmierci Jana Marii Vianneya. Autor dotyka przede wszystkim takich zagadnień, jak: nawrócenie w życiu kapłańskim, kapłan jako penitent, rachunek sumienia i warunek spowiedzi, szafarz, przymioty spowiednika (świętość, wrażliwość, szacunek), trudne spowiedzi. ${ }^{63}$

Problem pokuty, jako postawy i praktyki chrześcijanina w polskiej tradycji, został opracowany przez ks. A. Kraśnickiego. Opracowanie to obejmuje okres od XVI w. do czasu rozbiorów. Jest niezwykle cennym odzwierciedleniem tychże praktyk pokutnych w poszczególnych okresach liturgicznych, a także w związku z kluczowymi wspomnieniami świętych w życiu Kościoła w Polsce. ${ }^{64}$ Wpływ pokuty na życie duchowe znalazł odbicie w opracowaniu ks. J. Pryszmonta w nawiązaniu do konstytucji Penitemini papieża Pawła VI (17 II 1966).

${ }_{61}$ M. Sieniatycki, Pokuta kościelna wedtug Ojców zachodnich, PT 2(1921) nr 1, s. 33 -39; PT 2(1921) nr 2, s. 147-160; PT 2(1921) nr 3-4, s. 213-236; tenże, Spory na Zachodzie o dyscypline pokutna, PT 3(1922) nr 4, s. 273-301.

62 S. Moysa, Tendencje rozwojowe współczesnej teologii pokuty, CT 40(1970) nr 1, s. 63-76.

63 R. Selejdak, Kapłan penitentem i szafarzem sakramentu pokuty, CT 80(2010) nr 1, s. 57-80.

64 A. Kraśnicki, Posty w dawnej Polsce, s. 190-235, 299-382. 
Autor, odwołując się do tego dokumentu oraz wskazań II Soboru Watykańskiego, prezentuje przede wszystkim jej istotę, obowiązek, formy, praktyki, a także omawia przepisy dotyczące postów. ${ }^{65}$

Rozwój teologii pokuty związany jest organicznie z problemem sumienia człowieka i jego formacji. Zarówno sakrament pokuty, jak również pokuta pozasakramentalna odsłania jego wrażliwość, a także konfrontację z różnorodnością tendencji wynikających z rozwoju cywilizacji. ${ }^{66}$ To zagadnienie stało się przedmiotem niezwykle istotnego opracowania ks. S. Rosika, który, odwołując się do osiągnięć teologii moralnej, niezwykle istotnej dla teologii duchowości, polemizuje z etyką sytuacyjną reprezentowaną przez M. Heideggera, J. P. Sartrea, K. Bartha, E. Brunnera. ${ }^{67}$

Niejako dopełnieniem tych opracowań jest analiza dotycząca procesu permanentnego nawracania dokonana przez ks. M. Tatara. Wykazując jego kluczową rolę w procesie uświęcającym, autor przede wszystkim wyeksponował dynamiczność tego procesu, podkreślając jego charakterystyczne elementy na każdym etapie duchowego rozwoju chrześcijanina. ${ }^{68}$

Jak już zostało wspomniane w części dotyczącej duchowości patrystycznej, swoje miejsce mają także publikacje dotyczące sakramentu kapłaństwa i jego roli w życiu uświęcającym człowieka. Od strony patrystycznej jego istotę ukazał ks. L. Wasilkowski, polemizując z niebezpiecznym racjonalizmem oraz protestantyzmem. ${ }^{69}$ Kontynuacją tego zagadnienia jest opracowanie ks. R. Lukaszczyka dotyczące relacji kapłaństwa do biskupstwa. Ma ono szczególne znaczenie, ponieważ, odwołując się do reform II Soboru Watykańskiego, porządkuje odniesienie kapłaństwa sakramentalnego do powszechnego, jednocześnie wskazując na ich znaczenie dla duchowości

65 J. Pryszmont, Pokuta chrześcijańska wedtug Konstytucji „Paenitemini”, CT 37(1967) nr 1, s. 113-123.

66 A. Słomkowski, Teologia życia duchowego, Ząbki 2000, s. 164-168.

67 S. Rosik, Sytuacyjna funkcja sumienia, CT 37(1967) nr 4, s. 33-49.

68 M. Tatar, Nawrócenie fundamentalna zasada życia chrześcijańskiego, CT 76(2006) nr 1, s. 57-77.

69 L. Wasilkowski, Nauka św. Cypriana z Kartaginy, s. 4-33. 
communio Kościoła. ${ }^{70}$ Zagadnienie kapłaństwa, formacji w kontekście współczesnych wyzwań stało się przedmiotem opracowania ks. J. Popławskiego. Motywem do tej refleksji był Rok Kapłański ogłoszony przez papieża Benedykta XVI. ${ }^{71}$ Ksiądz I. Werbiński zaś z tych wyzwań wybrał jedno, które pozostaje nieustannym problemem - a mianowicie samotność. Autor wskazuje na różnorodność jej źródeł, rodzajów, jej świadomy wybór, dojrzewanie do niej a także owoce w życiu duchowym kapłana ${ }^{72}$. Wspomniany już ks. R. Selejdak, który zajmuje się duchowością kapłaństwa, opublikował istotne opracowanie dotyczące odniesienia tego powołania do fenomenu kierownictwa duchowego. Jest to zagadnienie kluczowe w procesie formacji, zarówno ze względu na istotę sakramentu kapłaństwa, jego duchowości, jak również pełnienia tej funkcji w stosunku do kapłanów, osób konsekrowanych oraz świeckich. To bardzo ważne opracowanie ze względu na współczesne zagrożenia, jakie pojawiły się w związku z tym środkiem uświęcającym. Autor podejmuje analizę przede wszystkim takich problemów, jak: odbicie ojcostwa duchowego Boga, ojcostwo duchowe w Kościele, przymioty kierownika duchowego (otwarcie na Ducha Świętego, delikatność), ojcostwo jako przejaw miłosierdzia Bożego, otwartość kierownika na modlitwę, komunikatywność, zachowanie tajemnicy, dojrzałość. ${ }^{73}$

Na pastoralny wymiar tejże duchowości kapłańskiej zwrócił uwagę w swoim opracowaniu ks. I. Mroczkowski. Analizując ten sakrament oraz powołanie, dokonał konfrontacji ze współczesnymi wyzwaniami, nawiązując do Raportu o stanie wiary kard. J. Ratzingera. Szczególnie istotnym elementem tego opracowania jest dogłębna

70 R. Łukaszczyk, Troskliwi współpracownicy urzędu biskupiego, CT 38(1968) nr 4, s. 25-34

71 J. Popławski, Kapłan wobec wyzwań współczesności, CT 80(2010) nr 2, S. $81-90$.

72 I. Werbiński, Znaczenie samotności dla duchowego życia kapłana, CT 80(2010) nr 2, s. 91-103.

73 R. Selejdak, Essere padre spirituale alle soglie del Terzo Millenio, CT 74(2004) nr spec., s. 149-163, 
analiza relacji kapłaństwa sakramentalnego i powszechnego. ${ }^{74}$ Przeniósł na grunt opracowania naukowego treść niezwykle istotnego dla formacji i duchowości kapłańskiej dokumentu, którym jest nowe $R a$ tio fundamentalis instututionis sacerdotalis (16 XII 2016). W świetle nowej rzeczywistości, w której rodzącą się powołania kapłańskie, rozwijają się i są formowane, konieczne stało się nowe spojrzenie na tożsamość kapłańską, etapy formacji i jej wymiary. ${ }^{75}$

Pośród opracowań dotyczących życia sakramentalnego, a także realizacji powołania do świętości, bardzo istotne miejsce zajmuje sakrament małżeństwa. ${ }^{76}$ Wpływa on w sposób istotny na duchowość świeckich, która będzie omawiana w oddzielnym paragrafie. Jej wymiaru trynitarnego, powołania, swoistego przymierza w Bogu dotyka w swoim opracowaniu A. Bławat. ${ }^{77}$ Kontynuując tę myśl, ks. Cz. Parzyszek dokonał analizy duchowości tegoż sakramentu w kontekście mocno dyskutowanej adhortacji papieża Franciszka Amoris laetitia (19 III 2016). Autor, opierając się na jej treści, wyeksponował nadprzyrodzony wymiar małżeńskiej komunii opartej na miłości wolnej i wyłącznej, która domaga się rozwoju duchowości liturgiczno-modlitewnej, będącej celebracją tegoż sakramentu w życiu małżonków i rodziny. ${ }^{78}$

Niestety, niewielki oddźwięk w publikacjach znajdują pozostałe sakramenty. Ksiądz J. Królikowski przedstawił opracowanie sakramentu bierzmowania w odniesieniu do duchowości. Odwołując się do św. Tomasza z Akwinu, wykazał odniesienie tego sakramentu

74 I. Mroczkowski, Duchowość polskiego duszpasterza, CT 58(1988) nr 1, s. 57-70.

75 R. Selejdak, Formacja kandydatów do kapłaństwa w świetle nowego „, Ratio fundamentalis institutionis sacerdotalis", CT 87(2017) nr 3, s. 97-133.

76 K. Lubowicki, Duchowość małżeństwa w nauczaniu Jana Pawła II, Kraków 2005, s. 86-96; M. Tatar, Duchowość matżeństwa i rodziny dzisiaj, Radom 2013, s. $14-18$.

77 A. Bławat, Z duchowości chrześcijańskiego małżeństwa, CT 47(1978) nr 3, s. $142-145$.

78 C. Parzyszek, Istotne elementy duchowości matzeństwa i rodziny $w$ świetle adhortacji „Amoris laetitia”, CT 87(2017) nr 2, s. 175-181. 
do antropologii, a także podjął takie zagadnienia, jak: otwarcie na wspólnotę Kościoła, uzdolnienie do walki oraz wyposażenie w dary pozwalające na bycie odważnym świadkiem wobec otaczającej rzeczywistości. ${ }^{79}$

$\mathrm{Na}$ temat bardzo istotnego dla duchowości chrześcijańskiej sakramentu chrztu, który określa się mianem pierwszego nawrócenia, mamy tylko jedno opracowanie, które ma charakter patrystyczny. Autorem jego jest ks. W. Kamczyk. ${ }^{80}$

Obok życia sakramentalnego źródłem dla rozwoju duchowości chrześcijańskiej jest słowo Boże. Analizując publikacje w opracowywanym periodyku, należy stwierdzić, że generalnie autorzy we wszystkich zagadnieniach przyjmują je za punkt wyjścia w swoich opracowaniach. Trzeba jednak zauważyć, że na gruncie teologii duchowości fundamentalnym jej wymiarem jest duchowość biblijna. Można zaobserwować próbę powrotu do jednej z najstarszych metod medytacyjnego odniesienia do słowa Bożego przez lectio divina. Jednakże wiąże się to z pewnym nowym spojrzeniem, którego dokonał ks. S. Haręzga. Odnosząc się do historii tej metody, a także praktyki monastycznej, zaprezentował nową drogę medytacji nad słowem Bożym. W praktycznym wprowadzeniu jej w życie oparł się na postulatach II Soboru Watykańskiego odnowy w tym względzie życia chrześcijanina. ${ }^{81}$

Kolejnym istotnym środkiem rozwoju życia duchowego chrześcijanina jest modlitwa. Należy stwierdzić, że jest ona jednym z kluczowych elementów dążenia do zjednoczenia z Bogiem, a także wyraża jego stan. W historii duchowości chrześcijańskiej ma bardzo liczne opracowania oraz analizy. Dotyczą one jej istoty, podstaw

79 J. Królikowski, Bierzmowanie jako sakrament duchowej otwartości w refleksji św. Tomasza z Akwinu, CT 59(1989) nr 3, s. 46-57.

80 W. Kamczyk, Duchowe i moralne implikacje chrztu wedtug Marka Eremity, s. $15-32$.

81 S. Haręzga, Ożywienie praktyki lectio divina we współczesnym Kościele, CT 61(1991) nr 4, s. 45-69. 
teologicznych i antropologicznych, metod oraz samej jej praktyki. ${ }^{82}$ Już pierwsze wydanie „Przeglądu Teologicznego” zawiera odniesienie do tej problematyki. Ksiądz A. Mocko, opierając się na Dziadach A. Mickiewicza, porusza problem modlitwy i zadośćuczynienia. ${ }^{83}$ Niestety, dalsza analiza opracowań w periodyku prowadzi do stwierdzenia, że w bardzo długim okresie ten temat nie był podejmowany. Dopiero ks. S. Urbański w kontekście czołowych przedstawicieli polskiej szkoły duchowości, o których będzie mowa nieco dalej, podejmuje to zagadnienie. ${ }^{84}$ Tenże element duchowości omawia także ks. E. Weron w odniesieniu do opracowanej przez niego formacji w Opus Dei, ze względu na beatyfikację założyciela tej drogi formacji Josemarii Escrivy de Balaguera przez Jana Pawła II (17 V 1992). ${ }^{85}$ Z kolei ks. W. Macko pozostawił systematyczne opracowanie modlitwy W życiu świeckich, powołując się na kard. S. Wyszyńskiego ${ }^{86}$ oraz w życiu kapłańskim, uwzględniając szczególne znaczenie modlitwy brewiarzowej. ${ }^{87}$ Do katalogu prowadzonych analiz modlitwy należy zaliczyć także źródłowe opracowanie oparte na przykładzie Teresy z los Andes przez ks. Jacka Hadrysia, ${ }^{88}$ a także jej patrystyczne ujęcie przez É. Escure-Delpeuch. ${ }^{89}$ Ostatnim akcentem, który odnajdujemy w publikacjach periodyku, jest opracowanie modlitwy w kontekście

82 S. Urbański, Teologia modlitwy, Warszawa 1999, s. 25-100; J. Aumann, Spiritual Theology, London 1980, s. 316-318.

83 A. Mocko, Teologia w „Dziadach” Mickiewicza, s. 17-18.

84 S. Urbański, Istota życia zakonnego według założycielek Zgromadzenia Sióstr św. Elżbiety, CT 59(1989) nr 1, s. 71-81.

85 E. Weron, Świecka duchowość członków Opus Dei. Po beatyfikacji Josemaria Escriva de Balguera, CT 64(1994) nr 2, s. 151-156.

86 W. Macko, Rola i znaczenie modlitwy w życiu świeckich $w$ świetle nauczania kard. Stefana Wyszyńskiego, CT 76(2006) nr 1, s. 93-102.

87 Tenże, Znaczenie modlitwy dla posługi i życia kapłańskiego w nauczaniu kard. Stefana Wyszyńskiego, CT 76(2006) nr 3, s. 83-91.

88 J. Hadryś, Życie modlitewne Teresy z los Andes wświetle jej Dziennika i Listów, s. 31-49.

89 É. Escure-Delpeuch, Modlitwa wedtug Marka Eremity, s. 33-50. 
wspólnotowym. Ksiądz M. Tatar prezentuje jej podwójny wymiar, tj. wspólnotowy oraz wspólnoto twórczy. ${ }^{90}$

Analiza publikacji zawartych w periodyku odsłania jeszcze jeden niezwykle istotny dla polskiej teologii duchowości aspekt. Jest nim wymiar maryjny. Sięgając do opracowań tego zagadnienia, możemy stwierdzić, że mamy do czynienia z podwójnym charakterem postrzegania duchowości maryjnej. Pierwszy z nich można określić mianem wzorczego, który widzi w Maryi wzór kobiecości, czystości, pobożności, macierzyństwa. Drugi zaś koncentruje się na „zawierzeniu”, polegając, jak twierdzi Jan Paweł II, na „wprowadzeniu” Maryi w życie chrześcijanina, w jego najgłębszą sferę intymnego życia z Bogiem..$^{91}$ Ten wymiar teologii duchowości znajduje swoje żywe odzwierciedlenie w kilku publikacjach. L. A. Krupa, analizując prawdę o niepokalanym poczęciu oraz wniebowzięciu, rozwinął charakter tejże duchowości maryjnej..$^{92}$ Następna publikacja ks. F. Zapłaty, opierając się na dogmatycznym ujęciu macierzyństwa Maryi, prezentuje duchowe aspekty Jej macierzyństwa wobec chrześcijanina. ${ }^{93}$ Kolejnym krokiem w odsłanianiu tajemnicy Maryi stała się analiza o. C. Napiórkowskiego. Wprawdzie zauważamy podejście dogmatyczne, ale rozwijając myśl soborową w tym względzie oraz odnosząc się do adhortacji apostolskiej Pawła VI Marialis cultus (2 II 1974), ukazał właściwy kształt pobożności maryjnej w kontekście ekumenicznym. ${ }^{94}$ Do tego katalogu autorów należy dołączyć ks. E. Werona, który, zajmując się duchowością świeckich, zaprezentował modele pobożności maryjnej w ich życiu. W tym celu oparł się na maryjności następujących wspólnot: Sodalicja Mariańska, Congregatio Mariana, Focolari, Mariapoli, Droga Neokatechumenalna. Analiza pozwoliła

90 M. Tatar, Wspólnotowy i wspólnototwórczy charakter modlitwy, CT 89(2019) nr 3, s. 111-136.

91 Jan Paweł II, Encyklika Redemptoris Mater, Rzym 25 III 1987, nr 45-46.

92 L. A. Krupa, Świętość Niepokalanej i Wniebowziętej Matki Zbawiciela, CT 25(1954) nr 3, s. 361-398.

93 F. Zapłata, Duchowe macierzyństwo Matki Bożej w świetle pouczeń magisterium Kościoła, CT 38(1968) nr 2, s. 69-88.

94 C. Napiórkowski, Maryja w pobożności katolickiej, CT 56(1986) nr 2, s. 19-33. 
mu stwierdzić, że są one następujące: sodalicyjno-egoriański, szensztacki, kolbiański .95

\section{Mistyka chrześcijańska}

Mistyka należy do zagadnień kluczowych dla teologii duchowości, ale jednocześnie stanowiących dość specyficzną jej część. W historii duchowości mamy ciągle do czynienia z ożywioną dyskusją nad miejscem mistyki, która jest współcześnie pojmowana w sposób niezwykle zróżnicowany. Niektórzy teologowie twierdzą, że jest integralną częścią procesu rozwoju duchowego chrześcijanina, zaś inni podkreślają jej nadzwyczajność i odrębność. ${ }^{96}$ Na gruncie mistyki występuje podwójny jej wymiar, tj. mistyka przeżyciowa oraz studyjna, która jest refleksją teologiczną nad tym doświadczeniem. Oba te wymiary są wobec siebie komplementarne. ${ }^{97}$ Jednakże w swym ujęciu naukowym ma ona specyficzną metodę a także terminologię. ${ }^{98}$ W ten sposób możliwe staje się opracowanie samej jej istoty, czyli stanu i intensywności zjednoczenia człowieka z Bogiem. Analiza tego doświadczenia pozwala wyznaczyć jego etapy, co jest przedmiotem mistyki studyjnej. Teologia życia mistycznego podejmuje także refleksję nad nadzwyczajnymi zjawiskami towarzyszącymi temu doświadczeniu, dokonuje oceny ich autentyczności a także pewnej klasyfikacji. Jednakże należy stwierdzić, że mimo swej spektakularności, nie należą one do istoty mistyki. Warto również podkreślić, że analiza tego doświadczenia uwzględnia różnorodność jego aspektów, rodząc opracowania dotyczące pewnego konkretnego wybranego elementu. Już w 1924 r. ukazała się recenzja autorstwa ks. A. Bogdanowicza dotycząca dzieła, które wydał benedyktyn

95 E. Weron, Modele pobożności maryjnej we współczesnym ruchu odnowy, CT 63(1993) nr 3, s. 131-138.

96 M. McIntosh, Mystical Theology, Oxford 1998, s. 5-9.

97 S. Urbański, Teologia życia mistycznego, Warszawa 1999, s. 29-36.

98 R. Garrigou-Lagrange, Trzy okresy życia wewnętrznego, tłum. T. Landy, Niepokalanów 2018, s. 411-413. 
o. Dom Louismet (1858-1926). Dotyczy ono bardzo istotnego elementu, jakim jest kontemplacja, jej natura i rodzaje ${ }^{99}$. Zagadnienie to podjął ks. E. Kulesza, który odwołuje się do Ryszarda od św. Wiktora. W dwóch artykułach mierzy się z próbą definicji mistyki, określenia jej przedmiotu oraz składników. Kolejne zagadnienia, które w kontekście kontemplacji omawia, to jej wymiar pneumatologiczny, centralne miejsce miłości, ale także znaczenie i charakter cierpienia oraz trudności człowieka w tym doświadczeniu. Niezwykle interesujące jest to, że wchodzi w polemikę z jej przeciwnikami takimi jak o. J. Maréchal. ${ }^{100}$ Bez wątpienia do grona tych, którzy podejmują tematykę z zakresu teologii mistyki należy o. J. Woroniecki. Jego analiza dotyczy elementów pochodzących od Dionizego Areopagity zawartych w tomizmie. Warto zaznaczyć, że to właśnie Dionizy ustalił terminologię mistyki, z której korzystamy do dnia dzisiejszego. Pozwala ona właściwie uchwycić zarówno podstawy, jak również naturę zjednoczenia z Bogiem. ${ }^{101}$

W całość dorobku publikowanego w „Collectanea Theologica” wpisuje się dorobek warszawskiej szkoły duchowości, której niekwestionowaną postacią jest ks. S. Urbański. Jego badania koncentrują się właśnie wokół problematyki mistyki przeżyciowej oraz studyjnej. Przedmiotem jego badań stała się s. Faustyna Kowalska, która wpisuje się w katalog wielkich mistyków Kościoła. Ksiądz S. Urbański, badając jej doświadczenia, przede wszystkim poddał analizie jej Dzienniczek, wydobywając takie treści, jak: pasywność, wyniesienie, poznanie Boga, noc ciemna ducha, przedmiot doświadczenia mistycznego, nadzwyczajne zjawiska (wizje mistyczne, zjawiska, ekstazy), charyzmaty umiejętność odczytania tajemnicy serc, proroctwo. ${ }^{102}$ Równie istotną publikacją jest opracowanie ks. M. Szymuli

99 Dom Louismet, La contemplation chrétienne (rec. A. Bogdanowicz), PT 5(1924) nr 1, s. 56-63.

${ }^{100}$ E. Kulesza, Kontemplacja mistyczna wedtug Ryszarda od św. Wiktora, CT 13/1931, s. 236-253, 383-405.

101 J. Woroniecki, Elementa dionizjańskie w tomizmie, CT 17/1936, s. 25-40.

${ }^{102}$ S. Urbański, Mystical aspects in the life of Blessed Faustyna Kowalska, CT 68(1998) nr spec., s. 225-242. 
odwołujące się do sympozjum na ATK (pierwsze ogólnopolskie) poświęconemu właśnie mistyce. W tymże opracowaniu odnajdujemy to, co jest fundamentem zajmowania się mistyką (właściwe jej rozumienie, mistyka inkarnacyjna, mistyka przeżyciowa, studyjna), ale również niebezpieczeństwa i zagrożenia fałszywą mistyką, czyli: techniki medytacyjne niechrześcijańskie u A. de Mello. Jest to zatem odpowiedź na pojawiające się potrzeby i wyzwania w tym zakresie. ${ }^{103} \mathrm{~W}$ tej przestrzeni naukowo-badawczej należy także umieścić publikację z zakresu duchowości sanjuanistycznej s. I. Ošmjanskiej. Karmelitanka z Łotwy analizuje sposób oddziaływania nadprzyrodzonej łaski wiary na naturę człowieka, prowadząc ku zjednoczeniu z Bogiem. ${ }^{104} \mathrm{Z}$ kolej ks. M. Tatar wskazuje na fenomen św. brata Alberta, jako przedstawiciela mistyki polskiej, prezentując jego mistyczną transformację. ${ }^{105}$

\section{Duchowość życia konsekrowanego}

Życie konsekrowane, obok powołania kapłańskiego oraz małżeńskiego, jest jednym z powołań, które są konstytutywne dla całego Kościoła katolickiego. ${ }^{106}$ Idąc za II Soborem Watykańskim, możemy stwierdzić, że jest to „znak królestwa niebieskiego”, ${ }^{107}$ zaś za Janem Pawłem II, iż „znajduje się w samym sercu Kościoła jako element o decydującym znaczeniu dla jego misji, ponieważ «wyraża najgłębszą istotę powołania chrześcijańskiego»»" ${ }^{108}$ Nie może więc zabraknąć dorobku naukowego w tym względzie. Znaczenie dla teologii ducho-

${ }^{103}$ M. Szymula, I Ogólnopolskie Sympozjum Mistyki-Sekcja Teologii Duchowości ATK, Warszawa 23 IV 1998, CT 68(1998) nr 1, s. 167-173.

${ }^{104}$ I. Ošmjanska, Teologalna cnota wiary wantropologii św. Jana od Krzyża, CT 82(2012) nr 3, s. 153-165.

${ }^{105}$ M. Tatar, Od duszy artysty do artyzmu ducha św. Brata Alberta, CT 84(2014) nr 1, s. 109-122.

${ }^{106}$ C. Parzyszek, Życie konsekrowane w posoborowym nauczaniu Kościoła, Ząbki 2007, s. 15-33.

${ }^{107}$ DZ 1; KK 44.

108 Jan Paweł II, Adhortacja apostolska Vita consecrata, Rzym 25 III 1996, nr 3. 
wości różnorodności form życia konsekrowanego oraz ich rozwoju zostało już podkreślone w punkcie dotyczącym historii duchowości. Można zauważyć, że zakony odegrały w tym względzie niezwykle istotną rolę. Jednakże sam aspekt historyczny jest niewystarczający, jeśli podejmujemy próbę wyjaśnienia istoty tego sposobu życia uświęcającego. Konieczne zatem jest sięgnięcie do jego istoty i natury. Kwerenda publikacji w „Przeglądzie Teologicznym”/,Collectanea Theologica", aż do publikacji o. K. Szafrańca OSPPE, wykazuje że $\mathrm{w}$ tej dziedzinie dominowały opracowania historii zakonów. Ojciec K. Szafraniec, pierwszy na łamach tego periodyku, opublikował kilka artykułów podejmujących teologię życia konsekrowanego w całej różnorodności aspektów. Przede wszystkim prezentuje specyfikę tego powołania, istotę, (opracowanie na podstawie myśli soborowej), naturę konsekracji, świadectwo życia oraz bycie znakiem, podążanie za Chrystusem, wspólnotowość i apostolat. ${ }^{109}$ Tematykę tę rozwinął w kolejnej publikacji, wykazując sens i wartość konsekracji zakonnej. ${ }^{110}$ Ten sam autor sukcesywnie podjął analizę roli Eucharystii w rozwoju życia zakonnego i jej wpływ na kształtowanie duchowości wspólnotowej. ${ }^{111}$ Kolejna jego publikacja dotyczy duchowości zakonnej w kontekście duchowości eklezjalnej. Podkreślając fenomen tego powołania, skupił swoją uwagę na takich zagadnieniach, jak: podstawy biblijne, konsekracja (określenie, istota, formy), życie wspólnotowe, zakorzenienie w Kościele - posługa prorocka, wymiar kontemplacyjny w modlitwie, pracy i apostolacie. ${ }^{112}$

Do grona teologów - analityków życia konsekrowanego dołączył ks. S. Urbański, również analizując fenomen rad ewangelicznych, wspólnotowość, jedność z Kościołem, źródła tej formy życia, czyli sakramenty, modlitwa, kult Najświętszego Serca Jezusa, nabożeństwo

${ }^{109}$ K. Szafraniec, Teologia życia zakonnego, CT 50(1980) nr 4, s. 5-26.

110 Tenże, Konsekracja zakonna; sens i wartość, CT 54(1984) nr 1, s. 37-44.

111 Tenże, Życie eucharystyczne wspólnoty zakonnej, CT 52(1982) nr 4, s. 5-19.

112 Tenże, Życie zakonne w Kościele współczesnym, CT 53(1983) nr 4, s. 5-35. 
do Matki Bożej. ${ }^{113}$ Pewną nowością, która ukazała się, jest publikacja dotycząca dziewictwa konsekrowanego autorstwa P. Libery. Jest to nawiązanie do św. Ambrożego i jego ujęcia, a także decyzji Jana Pawła II o zwołaniu IX Zgromadzenia Zwyczajnego Synodu Biskupów w 1994 r., którego Instrumentum laboris zostało zatytułowane De vita consecrata deque eius munere in Ecclesia et in Mundo. ${ }^{114}$ To z jednej strony powrót do źródeł tej formy życia, zaś z drugiej odpowiedź na pojawiające się nowe formy życia konsekrowanego. ${ }^{115}$

Kolejny cykl analiz teologicznych dostarczył ks. Cz. Parzyszek, który w kontekście dokumentu Kongregacji ds. Instytutów Życia Konsekrowanego i Stowarzyszeń Życia Apostolskiego Postuga władzy i postuszeństwo (11 V 2008), a także Vita consecrata Jana Pawła II, zaprezentował nowe spojrzenie na posłuszeństwo, a także rolę władzy w odniesieniu do życia braterskiego oraz wypełnienia misji. Przede wszystkim podkreślił takie aspekty, jak: priorytety w wypełnianiu władzy, godność osoby, wzbudzanie nadziei i odwagi, ożywianie charyzmatu, życie zmysłem Kościoła, a także towarzyszenie w formacji. ${ }^{116}$ Kolejną jego cenną publikacją w tej tematyce jest analiza życia i formacji zakonnej w kontekście Roku Życia Konsekrowanego, który decyzją papieża Franciszka rozpoczął się 30 listopada 2014 r. i podejmował odnowę charyzmatyczności tego powołania. ${ }^{117}$ Obok opracowań od strony pozytywnej zostało opublikowane także opracowanie dotyczące pojawiającego się kryzysu. Jego początki zauważył o. M. Chaberek OP w USA. Zwrócił uwagę na takie wyzwania, jak: indywidualizm, rewolucja seksualna,

113 S. Urbański, Istota życia zakonnego wedtug założycielek Zgromadzenia Sióstr św. Elżbiety, CT 59(1989) nr 1, s. 71-81.

${ }^{114}$ Instrumentum laboris De vita consecrata deque eius munere in Ecclesia et in mundo, Synodus Episcoporum IX Coetus Generalis Ordinarius, Libreria Editrice Vaticana, 1994.

115 P. Libera, Duchowość dziewictwa konsekrowanego w świetle pism św. Ambrożego z Mediolanu, s. 87-100.

${ }^{116}$ C. Parzyszek, Nowe spojrzenie na postuszeństwo i posługę władzy zakonnej, CT 79(2009) nr 1, s. 85-102.

117 Tenże, Rok życia konsekrowanego, CT 85(2015) nr 1, s. 175-180. 
posoborowe rozbicie. Wówczas w USA występowały dwie formy stowarzyszeń życia konsekrowanego kobiet: CMSWR (Conference of Major Superiors of Women Religious) oraz LCWR (Leadership Conference of Women Religious). To drugie stowarzyszenie w sposób otwarty wystąpiło przeciw Janowi Pawłowi II, czego efektem była wizytacja apostolska. ${ }^{118}$

\section{Duchowość laikatu}

Rola i znaczenie laikatu w życiu i rozwoju Kościoła została w dużej mierze zauważona i doceniona na II Soborze Watykańskim. Przede wszystkim podjęto próbę zdefiniowania tej formy powołania i życia: „Przez pojęcie «świeccy» rozumie się tutaj wszystkich wiernych, którzy nie są członkami stanu duchownego i stanu zakonnego prawnie ustanowionego w Kościele". ${ }^{119}$ Na sposób rozumienia roli świeckich bez wątpienia wpłynęła reformacja a następnie okres oświecenia. Sytuacja w tym względzie w Kościele katolickim zmieniała się pod wpływem takich teologów, jak Y. Congar, K Rahner, E. Schillebeeckx, F. X. Arnold. Należy podkreślić wrażliwość wobec tego zagadnienia papieża Piusa XII, a także wpływ Kongresów Apostolatu Świeckich (1951, 1957, 1967). Jak już zostało zaznaczone, przypieczętowaniem zmian były obrady i dokumenty II Soboru Watykańskiego. ${ }^{120}$ Warto podkreślić, że na ich powstanie i redakcję znamienity wpływ wywarł bp K. Wojtyła. On także jest późniejszym zwolennikiem eksponowania teologii i roli świeckich. Nie bez znaczenia pozostaje w tym względzie niezwykle istotny wkład teologiczny kard. J. Ratzingera/Benedykta XVI oraz papieża Franciszka. Kluczowym dokumentem pozostaje jednak adhortacja apostolska Jana Pawła II Christifideles laici, którą bez wątpienia można określić jako ,wielką kartę teologii laikatu”. Papież, przyj-

${ }_{118}$ M. Chaberek, CMSWR kontra LCWR. O kryzysie i odnowie życia konsekrowanego w USA, CT 88(2018) nr 3, s. 115-135.

119 KK 31.

${ }^{120}$ KK 30-38; KDK 43, 52, 62; DA 2-4; DM, 15, $21,41$. 
mując definicję II Soboru Watykańskiego, podkreślił, nawiązując do nauczania papieża Piusa XII, że świeccy (laikat) nie tyle przynależą do Kościoła, ale „są Kościołem”. ${ }^{121}$ Wyakcentowanie specyfiki laikatu, wiążącej się z właściwym sobie charakterem życia i drogi uświęcającej, zyskało potwierdzenie w nauczaniu Kościoła w tezie o powszechnym powołaniu do świętości. ${ }^{122}$ Możemy zatem mówić o specyfice charyzmatyczności życia i uświęcania w świecie.

Teologia laikatu nie mogła zatem nie znaleźć odzwierciedlenia w publikacjach tak poważnego i istotnego dla uprawianej w Polsce teologii periodyku. Należy zauważyć, że w przeważającej liczbie publikacji opracowania odnoszą się do duchowości chrześcijanina, a zatem przekraczają granice zawężenia do stanu duchownego czy też życia konsekrowanego, analizując życie słowem Bożym, życie sakramentalne, formację sumienia, praktyki ascetyczne, kształtowanie postawy chrześcijanina-świadka. Jednakże pierwsze publikacje dotyczące bezpośrednio duchowości laikatu pojawiają się dopiero w 1971 r., a więc dość długo po II Soborze Watykańskim. Ten kierunek pracy naukowo-badawczej rozpoczął ks. E. Weron. Opierając się na teologii K. Rahnera oraz wykładni II Soboru Watykańskiego, nakreślił zasadność mówienia o duchowości świeckich a także jej specyfikę. ${ }^{123}$ Nakreślenie eklezjalnych podstaw pozwoliło mu podjąć analizę dotyczącą podstaw pneumatologicznych oraz charyzmatyczności tejże duchowości. ${ }^{124}$

Kolejne jego artykuły podejmują systematycznie kluczowe dla duchowości zagadnienia. Między innymi dotyczą one takich zagadnień, jak: specyfika życia radami ewangelicznymi w świecie. ${ }^{125} \mathrm{~W}$ opranr 9.

${ }^{121}$ Jan Paweł II, Adhortacja apostolska Christifideles laici, Rzym 30 XII 1988,

122 KK 39.

${ }^{123}$ E. Weron, Teologiczne podstawy duchowości Wcielenia, CT 41(1971) nr 1, s. $71-80$.

124 Tenże, Charyzmaty Ducha Świętego w życiu i apostolstwie ludzi świeckich, CT 42(1972) nr 3, s. 45-56.

${ }^{125}$ Tenże, Rady ewangeliczne w życiu ludzi świeckich, CT 44(1974) nr 1, s. 145-151. 
cowaniu tego zagadnienia towarzyszy mu ks. J. Witek, publikując w tym samym tomie nieco poszerzone opracowanie. ${ }^{126}$ Zauważamy, że ciągle jednak pozostawała do wyjaśnienia kwestia tożsamości laikatu, jego miejsca w Kościele i własnej drogi uświęcającej, Z tego względu ks. E. Weron, w reakcji na opracowanie Y. Congara umieszczone w Dictionaire de spiritualité ascétique (Paris 1976), nakreślił historię duchowości laikatu oraz rozwinął encyklopedyczne ujęcie. ${ }^{127}$ Kolejnym istotnym wydarzeniem, które niejako sprowokowało prace nad teologią duchowości świeckich, była zapowiedź Synodu Biskupów zwołanego na rok 1987 i mającego za przedmiot obrad rolę świeckich w Kościele. Wydarzenie to stało się podstawą do opracowania przez ks. E. Werona tego zagadnienia na podstawie Lineamenta Synodu Biskupów Posłannictwo i powołania ludzi świeckich w Kościele $i w$ świecie - w dwadzieścia lat po Soborze Watykańskim II. ${ }^{128}$

Kolejnym pogłębieniem zagadnienia podjętego na Synodzie była teologiczna analiza duchowości tego stanu w kontekście tajemnicy wcielenia. Ksiądz E. Weron poddał po raz kolejny analizie takie zagadnienia, jak: odrębność powołania, świeckość, rady ewangeliczne w życiu świeckich, życie sakramentalne, małżeństwo i rodzina, ale także praca ludzka, opcja na rzecz ubogich oraz działalność polityczna. ${ }^{129}$

$\mathrm{Na}$ rozwój teologii duchowości świeckich nie pozostało bez wpływu ogłoszenie przez Jana Pawła II 15 VIII 1989 r. adhortacji apostolskiej Redemptoris custos. Na kanwie tego dokumentu również ks. E. Weron podjął refleksję nad jej odniesieniem do duchowości świeckich. Mimo ciągle rozwijającej się myśli teologicznej w tym względzie autor wrócił po raz kolejny do analizy teologicznych podstaw duchowości tego powołania, wykazując konieczność oparcia na

126 J. Witek, Rady ewangeliczne a przykazania i cnoty moralne w życiu świeckim, CT 44(1974) nr 1, s. 151-158.

127 E. Weron, Duchowość własna laikatu, CT 48(1978) nr 2, s. 165-171.

128 Tenże, Problem wychowania i duchowości laikatu wedtug „Lineamenta” Synodu Biskupów, CT 56(1986) nr 2, s. 115-121.

129 Tenże, Inkarnacyjna duchowość laikatu, CT 60(1990) nr 1, s. 95-108. 
fundamencie biblijnym. ${ }^{130}$ Niejako dopełnieniem tych jego poszukiwań stała się posynodalna adhortacja apostolska Jana Pawła II Christifideles laici (30 XII 1988). Ten „milowy krok” w teologii laikatu pozwolił ks. E. Weronowi nakreślić zasadnicze przestrzenie rozwoju duchowego w tym stanie życia chrześcijanina. Odnajdujemy w jego opracowaniu bogactwo eklezjalnej duchowości komunijnej, misyjnej, małżeńsko-rodzinnej, rozwoju w życiu społeczno-politycznym. ${ }^{131}$

Systematyczne opracowywanie teologii duchowości tego stanu życia znalazło odzwierciedlenie w reakcji na rozwój kultu miłosierdzia Bożego. Jedenaście lat przed beatyfikacją św. s. Faustyny, w momencie pozwolenia przez Kongregację (19 VI 1981) na prowadzenie procesu, ks. E. Weron, podjął tę problematykę w odniesieniu do świeckich. ${ }^{132}$

Motywem opracowania następnych aspektów duchowości laikatu (modlitwa, praca, współpraca z Bogiem w dziele przemiany świata, uświęcenie pracy, uświęcenie przez pracę, uświęcenie innych przez pracę), stała się beatyfikacja Josemarii Escrivy de Balaguera (15 V 1992). ${ }^{133}$ Warszawski teolog duchowości świeckich w swoich analizach podjął także zagadnienie kierownictwa duchowego świeckich i sprawowanego przez świeckich, odwołując się do takich przykładów, jak: Tertulian, Klemens Aleksandryjski, Katarzyna ze Sieny, Tomasz à Kempis, Franciszek Salezy, H. Koźmiński, św. Jan Bosko, św. Wincenty Pallotti, E. Bojanowski, Jan Tyranowski, Chiara Lubich, Kiko Arguello. ${ }^{134}$ Konkludując, należy stwierdzić, że ks. E. Weron należy do prekursorów oraz czołowych teologów ducho-

${ }_{130}$ Tenże, Czy istnienie Boże powołanie do świeckiego stanu życia? CT 60(1990) nr 1, s. 126-132.

${ }^{131}$ Tenże, Uczestnictwo świeckich w budowaniu cywilizacji mitości w świetle adhortacji „Christifideles laici”, CT 63(1993) nr 2, s. 153-159.

132 Tenże, Rola laikatu w ruchu czcicieli Miłosierdzia Bożego, CT 52(1982) nr 1, s. $137-145$.

${ }^{133}$ Tenże, Świecka duchowość członków Opus Dei. Po beatyfikacji Josemaria Escriva de Balguera, s. 151-156.

${ }^{134}$ Tenże, Kierownictwo duchowe realizowane przez świeckich w postudze nowej ewangelizacji, CT 70(2000) nr 1, s. 160-170. 
wości świeckich. Soborowe otwarcie Kościoła na rolę i znaczenie laikatu zaowocowało rozwojem ruchów i stowarzyszeń katolickich. Formacja, która dokonywała się i dokonuje w nich, jest odpowiedzią na duchowe zapotrzebowanie w Kościele. Jednocześnie prowadzi do podejmowania działań misyjno-ewangelizacyjnych, które, jak twierdzą ojcowie soborowi, winno posiadać działanie uzdrawiające wobec świata. ${ }^{135}$ Jan Paweł II w swoim programowym dla laikatu dokumencie, czyli Christifideles laici, podkreślił charyzmatyczność ich życia, ${ }^{136}$ ale jednocześnie, omawiając ich zaangażowanie w struktury Kościoła, zaznaczył, że „możemy mówić o nowej epoce zrzeszeń katolików świeckich". ${ }^{137}$ Odsłaniają one powołanie do świętości, stają się narzędziami jej rozwoju, rodzą żywe świadectwo, realizują charakter powołania Kościoła, prowadzą do transformacji rzeczywistości świata. ${ }^{138}$

Nakreślenie tych wymiarów, a jednocześnie głęboka analiza teologiczna, znalazły swoje odzwierciedlenie w publikacjach autorów „Collectanea Theologica”. Już sama analiza historycznych aspektów powstających zakonów, zgromadzeń i instytutów życia konsekrowanego jest świadectwem żywotności charyzmatycznej Kościoła. W wielu przypadkach duchowość ta ma swój początek w pragnieniach i dążeniach świeckich. Warto zaznaczyć, że w historii Kościoła takim przedstawicielem duchowości laikatu był św. Tomasz More. ${ }^{139}$ Jednakże w sposób akademicki i bezpośredni zagadnienia charyzmatycznej duchowości laikatu w ruchach, stowarzyszenia i zrzeszeniach dotknął ks. D. Tomczyk, ukazując odnowę i rozwój w ruchu charyzmatycznym. Przede wszystkim wskazał na charakter rozwijającej się duchowości. ${ }^{140}$ Kontynuatorem tej myśli jest ks. S. Zarzycki, który

${ }^{135} \mathrm{KK} 36$.

136 Jan Paweł II, Christifideles laici, nr 24.

137 Tamże, nr 29.

138 Tamże, nr 30.

${ }^{139}$ G. Antoniuk, Duchowość Tomasza More'a, s. 112- 120.

${ }^{140}$ D. Tomczyk, Duchowość ruchu charyzmatycznego, CT 58(1987) nr 3, s. 37-46. 
wskazał na założenia, specyfikę formacji świeckich oraz koncepcję duchowości. ${ }^{141}$

\section{Duchowość w dialogu}

Analiza duchowości chrześcijańskiej pozwala stwierdzić, że ze swojej natury nie może ona pozostawać wyizolowana, sprywatyzowana czy też ekskluzywna. Zarówno duchowość przeżyciowa, jak również teologiczna refleksja nad nią wchodzi w relację z otaczającą rzeczywistością. Jak już wielokrotnie zostało stwierdzone, jej powinnością jest uświęcająca przemiana samego człowieka, społeczeństwa, a także świata, w którym żyje. W swojej naturze jest ona spełnianiem niegasnącego pragnienia człowieka wiążącego się z pragnieniem doświadczenia pełni. Jak twierdzi, R. Rolheiser, idący za słowami św. Augustyna i parafrazujący je, ,istnieje w nas fundamentalny niepokój, jakiś ogień nie do ugaszenia, który uniemożliwia nam zaznanie w tym życiu pełnego ukojenia”. ${ }^{142}$ Publikacje zawarte w „Przeglądzie Teologicznym”/,Collectanea Theologica” odzwierciedlają swoją treścią nie tylko analizę tychże naturalnych, ale przede wszystkim nadprzyrodzonych pragnień człowieka w każdym człowieku i czasie. Z tego względu autorzy publikacji podejmują zagadnienia, które są odpowiedzią na pojawiające się w świecie oraz w teologii wyzwania.

Teologia duchowości ze swej natury musi być interdyscyplinarna, co oznacza, że pozostaje w ścisłej współpracy z dziedzinami teologicznymi i pozateologicznymi posługującymi się własną metodologią badawczą, korzystając z ich dorobku. Opracowanie duchowości patrystycznej wykazało bardzo głęboki związek duchowości z tą dziedziną. Właściwie można powiedzieć, że patrystyka oraz patrologia są obrazem dynamiki rozwijającej się w starożytności chrześcijańskiej duchowości jako dziedziny teologicznej. Z kolei historia duchowości

${ }^{141}$ S. Zarzycki, Sprawozdanie z sympozjum duchowości Akcji Katolickiej (25 V 1996), CT 67(1997) nr 2, s. 149-154.

${ }^{142}$ R. Rolheiser, W poszukiwaniu duchowości XXI wieku, tłum. K. Tybinka, Kraków, 2005, s. 15. 
a także hagiografia jest zarówno naukowo-badawczą, jak również praktyczną egzemplifikacją rozwoju duchowego chrześcijanina na przestrzeni wieków. Dogłębne analizy teologii duchowości domagają się oparcia na naukach biblijnych, korzystając z ich dorobku w tzw. duchowości biblijnej. Bezwzględnie koniecznym fundamentem jest teologia dogmatyczna, fundamentalna, liturgika oraz inne dziedziny teologiczne. W sposób szczególny pozostaje w związku organicznym z teologią moralną, z której wyrosła. Stwierdzenia te są dość oczywiste i uzasadniają, że uprawianie duchowości ma charakter wybitnie interdyscyplinarny, co wykazuje dotychczasowa analiza opracowań zawartych w periodyku.

Teologiczna analiza duchowości nie może pozostawać obojętna i nie uwzględniać w swojej pracy naukowo-badawczej także takich dziedzin, jak antropologia, psychologia, socjologia a nawet nauka społeczna Kościoła. Taki charakter ma opracowanie, którym jest recenzja publikacji W. Rubczyńskiego, Filozofia życia duchowego napisana przez ks. F. Sawickiego. Motywem tej książki jest sytuacja wojny i zagrożenia życia duchowego, które się z nią wiąże. Jednocześnie znajdujemy wyeksponowanie takich cech, jak wytrzymałość niezniszczalność duchowa moc i ład. ${ }^{143}$

W zakresie interdyscyplinarnych badań mieści się publikacja ks. E. Ożoga. Opracowanie to ma szczególne znaczenie, ponieważ nie neguje znaczenia psychologii, ale osadza ją we właściwym miejscy formacji duchowej. ${ }^{144}$ Relacja duchowości do psychologii stała się także przedmiotem opracowania o. M. Falkowskiego. Autor podjął się wyjaśnienia kluczowych zagadnień tego zakresu, w kontekście zagrożenia psychologizacją duchowości. Stara się odpowiedzieć na zasadnicze pytanie dotyczące kompetencji psychologii w zajmowaniu się duchowością, a następnie analizuje niebezpieczeństwo

${ }^{143}$ F. Sawicki, W. Rubczyński, Filozofia życia duchowego (rec.), CT 6/1925, s. 226-231.

${ }^{144}$ E. Ożóg, Próba określenia sylwetki psychicznej współczesnego zakonnika i wptywu środowiska zakonnego na ksztaltowanie jego osobowości, CT 46(1976) nr 2, s. 81-97. 
redukcjonizmu psychologicznego, by wskazać szczególną rolę psychologii personalistycznej $\mathrm{w}$ formacji chrześcijanina. ${ }^{145} \mathrm{Z}$ kolei P. Stawiński opublikował badania na gruncie socjologicznym oparte na duchowości, jako kategorii badawczej, w rzeczywistości amerykańskiej. Jest to niezwykle interesujące ujęcie, ponieważ teologia duchowości nie prowadzi swoich badań metodami socjologicznymi. Zastosowanie tychże metod odnosiło się do rozumienia samego terminu „duchowość” i rzeczywistości, którą opisuje. W tym kontekście zostały zaprezentowane wyniki dotyczące pojmowania religijności w kategoriach „szwedzkiego stołu” czy też religijności prywatnej. Uwzględniono także kategorię bezwyznaniowości. ${ }^{146}$

Jedną z przestrzeni dialogu duchowości w wyzwaniami cywilizacyjnymi jest opracowanie M. Dąbrowskiej. Jest ono reakcją na encyklikę Jana Pawła II Laborem exercens (14 IX 1981). Praca, jak możemy zauważyć w historii duchowości, była dość szeroko omawianym elementem na gruncie teologicznym. Warto wspomnieć, że w życiu zakonnym duchowość stanowiła i stanowi istotny czynnik formacyjny. Autorka publikacji, nawiązując do podstaw biblijnych a także teologicznych, nakreśliła zasadnicze elementy duchowości pracy, tj. udział człowieka w akcie stwórczym Boga, związek pracy z misterium paschalnym, uświęcający współudział człowieka w consecratio mundi. ${ }^{147}$ Zagadnienie to także omawia ks. E. Weron w kontekście inkarnacyjnej duchowości laikatu ${ }^{148}$ a także specyfikę formacji w Opus Dei. ${ }^{149}$

Wychodząc poza dziedziny teologiczne, teologia duchowości poddaje analizie szeroko rozumianą kulturę człowieka. Takiej konfrontacji dokonał W. Urbanowicz, wykazując, że współcześnie mamy do czynienia z kulturą o charakterze naturalnym, która zamyka

${ }^{145}$ M. Falkowski, Czy duchowości potrzebna jest psychologia? O dojrzalej formacji duchowej chrześcijanina dziś, CT 88(2018) nr 3, s. 147-157.

${ }^{146}$ P. Stawiński, Socjologia duchowości. Wybrane aspekty $w$ kontekście amerykańskim, CT 82 (2012) nr 2, s. 131-144.

${ }_{147}$ M. Dąbrowska, Duchowość pracy ludzkiej, CT 53(1983) nr 1, s. 126-131.

${ }^{148}$ E. Weron, Inkarnacyjna duchowość laikatu, s. 95-108.

149 Tenże, Świecka duchowość członków Opus Dei, s. 151-156. 
człowieka w rzeczywistości doczesnej. Jej przeciwstawieniem jest kultura przekraczająca samego człowieka i świat, mająca charakter umysłowy i moralny. ${ }^{150} \mathrm{~W}$ tym kontekście niezwykle cenna jest publikacja ks. S. Moysy, który w kontekście duchowości omówił rozeznawanie duchowe w odniesieniu do znaków czasu. Podkreślił charakter ich rozpoznawania i odczytywania w duchu wiary i metody ignacjańskiej. ${ }^{151}$ Pewnym dopowiedzeniem i uzupełnieniem tej tematyki jest publikacja ks. Cz. Parzyszka , która jest recenzją publikacji posympozjalnej na temat duchowości w cywilizacji wielkomiejskiej. ${ }^{152}$

\section{Polskie szkoły duchowości}

Na rozwój polskiej duchowości wywarły wpływ zakony, które rozwijały się na terenie Polski, mające bardzo często swoje źródło poza jej granicami. Nie bez znaczenia pozostaje także wiedza i przygotowanie polskich teologów duchowości na uniwersytetach i wydziałach teologicznych europejskich oraz światowych. Istotne jest jednak to, aby zauważyć, że pod tym względem mamy do czynienia z oryginalną polską myślą teologiczną, która kształtowała się wraz z rozwojem Kościoła. Obserwacja dokonań w tym zakresie pozwala stwierdzić, że publikacje w omawianym periodyku wpisują się w cały dorobek polskich teologów duchowości. Jak twierdzi ks. prof. S. Urbański, teolog mistyki, „,największy rozwój teologii życia duchowego i mistycznego następuje pod koniec XIX wieku i na początku XX wieku". ${ }^{153}$ Wiele lat pracy naukowo-badawczej polskich środowisk teologicznych prowadzi do wniosku, że możemy mówić o następujących oryginalnych szkołach duchowości: mariańska (o. S. Papczyński), honoracka (o. Honorat Koźmiński), zmartwychwstańcza

${ }^{150}$ W. Urmanowicz, Kultura a doskonałość człowieka, CT 31(1960) nr 1, s. 15-32.

${ }^{151}$ S. Moysa, Znaki czasu a rozeznawanie duchowe, CT 47(1977) nr 4, s. 23-44.

152 C. Parzyszek, Duchowość wielkich miast, CT 88(2018) nr 4, s. 216-217.

${ }^{153}$ S. Urbański, Polska szkoła duchowości, Warszawa 2016, s. 9-10. 
(B. Jański, ks. P. Semenenko, ks. H. Kajsiewicz, ks. P. Smolikowski, s. M. Darowska, s. J. Karska, siostry J i C. Borzęckie). ${ }^{154}$

Warto zatem dokonać analizy pewnych oddźwięków wymienionych szkół w publikacjach „Przeglądu Teologicznego”/,Collectanea Theologica", ponieważ czas rozwoju tychże szkół jest zbieżny z czasem rozwoju czasopisma. Jak już zostało zauważone, jednym z czołowych teologów duchowości, którego dorobek odnajdujemy w publikacjach, jest ks. A. Żychliński. Równie cenne publikacje z zakresu mistyki umieszczali ks. E. Kulesza, o. J. Woroniecki (mistyka studyjna), ks. F Blachnicki, ks. E. Weron, o. K. Szafraniec. Już w 1949 r. ukazała się w „Colletanea Thelogica” publikacja Z. Obertyńskiego dotycząca Marceliny Darowskiej. ${ }^{155}$ W 1989 r. swoje publikacje, które dotyczą polskiej szkoły duchowości, na łamach czasopisma rozpoczął ks. prof. S. Urbański, zajmując się takimi postaciami, jak: Klara Dorota Wolf, Matylda Merkert, Maria Merkert, Franciszka Werner, eksponując przede wszystkim teologię duchowości zakonnej w Polsce i jej kluczowe elementy. ${ }^{156}$ Kolejne jego opracowanie dotyczyło niezwykle znanej dziś mistyczki, s. Faustyny Kowalskiej, która została beatyfikowana 18 IV 1993 r., zaś kanonizowana 30 IV 2000 r. przez Jana Pawła II. Autor po przebadaniu Dzienniczka prezentuje ją jako polską mistyczkę (mistyka przeżyciowa) z niezwykle istotnym przesłaniem dla Kościoła i świata. ${ }^{157}$ Kolejna jego publikacja, odzwierciedlająca prowadzone badania nad polską szkołą duchowości i nosząca dokładnie taki tytuł, dotyczy przedstawicieli szkoły zmartwychwstańczej, tj. ks. P. Semenenki, ks. P. Smolikowskiego, M. Darowskiej. Autor eksponuje przede wszystkim charakterystyczne elementy tejże duchowości, czyli pierwszeństwo

154 Tamże, s. 12.

155 Z. Obertyński, Graces mistiques extraordinaries chez la mere Marie Marcelline Darowska, CT 21(1949) nr 4, s. 469-532.

${ }^{156} \mathrm{~S}$. Urbański, Istota życia zakonnego wedtug założycielek Zgromadzenia Sióstr św. Elżbiety, s. 71-81.

157 Tenże, Mystical aspects in the life of Blessed Faustyna Kowalska, s. 225-242. 
miłości, personalizm, poznanie siebie w Bogu oraz integrację na drodze rozwoju duchowego. ${ }^{158}$

Reakcją na beatyfikację Anieli Salawy (13 VIII 1991) przez Jana Pawła II było opracowanie biografii eksponującej jej życie uświęcające jako polskiej mistyczki, tercjarki franciszkańskiej, autorki Dziennika. ${ }^{159}$

$$
* * *
$$

Rozwój myśli teologicznej na przestrzeni wieków życia i działalności Kościoła znajduje odzwierciedlenie w dorobku, który zachował się $\mathrm{w}$ postaci publikacji. Jednym z głównych i zarazem poważnych czasopism teologicznych w Polsce jest „Collectanea Theologica”, która ma swoje korzenie we Lwowie, a po wojnie związana jest z warszawskim środowiskiem naukowo-teologicznym. Takie określenie ma jednak nieco mylący charakter, ponieważ, jak wskazuje analiza publikacji, swoim zasięgiem obejmuje nie tylko obszar Polski, ale również wykracza poza jego granice, o czym świadczą publikacje autorów obcokrajowych i obcojęzycznych. Bez wątpienia czasopismo to stało się niezwykle poważnym i bogatym źródłem oraz płaszczyzną dla rozwoju teologii duchowości. Jego zaistnienie wiąże się z usamodzielnieniem tejże dziedziny teologicznej i z tego względu od samego początku jego istnienia odnajdujemy niezwykle cenny i poważny materiał z zakresu duchowości. Analiza publikacji, które są efektem prowadzonych na przestrzeni stu lat badań, pozwala stwierdzić, że mamy do czynienia z niezwykłym i zróżnicowanym bogactwem tego dorobku.

W opracowaniu nakreślono główne kierunki rozwoju teologii duchowości i ich udokumentowanie. Można skonstatować, że publikacje te są odzwierciedleniem tendencji i kierunków teologicznych w Kościele powszechnym. Zarówno dokumenty Kościoła, jak również

158 Tenże, The Polish School of Spirituality, CT 68(1998) nr spec., s. 185-199

${ }^{159}$ S. A. Lewandowska, Świeckość beatyfikowana. Beatyfikacja Anieli Salawy $w$ Krakowie, CT 63(1993) nr 3, s. 138-142. 
papieży stawały się inspiracją dla autorów. Niezwykle istotny jest rozwój rodzimej polskiej teologii, mającej własną specyfikę i wnoszącej bogaty dorobek w życie całego Kościoła. Podkreślić należy, że opracowania są wyrazem i dowodem poszukiwania odpowiedzi na wydarzenia o charakterze społecznym, politycznym i ekonomicznym. Jak możemy zauważyć, bardzo istotnym elementem jest interdyscyplinarny sposób uprawiania teologii duchowości. Dowodzi to, że „Collectanea Theologica”, jako stuletnie czasopismo teologiczne, odgrywa bardzo istotną rolę w rozwoju tego kierunku teologii.

ks. Marek TATAR

Słowa kluczowe: duchowość; mistyka; duchowość laikatu; teologia duchowości; hagiografia; historia duchowości; duchowość dialogiczna; duchowość sakramentalna

Keywords: spirituality; mysticism; spirituality of laity; theology of spirituality; hagiography; history of spirituality; dialogical spirituality; sacramental spirituality

\section{Elements of the Theology of Spirituality in "Collectanea Theologica" 1920-2020}

\section{Summary}

The development of theology over the centuries of the Church's life and activity is accomplished through publications. They express the theologians' positions, opinions and hypotheses. Among Polish theological journals, "Collectanea Theologica", which has its origins in Lviv ("Przegląd Teologiczny"), plays a special role. Though it is connected with the Warsaw theological environment, it not only covers Poland but also goes beyond its borders, as evidenced by the foreign publications and foreign-language authors. Undoubtedly, this journal has become a very serious and rich source of and platform for the development of the theology of spirituality. Its existence is connected with the independence of this branch of the 
theology, and therefore from the beginning of its existence we find in the journal highly valuable and serious materials on spirituality.

The analysis of the publications, which are the result of research conducted over a hundred years, allows us to conclude that we are dealing with an unusual and multidirectional wealth. It should be stated that the publications present an interdisciplinary nature of the research conducted. The study outlines the main directions of the development of the theology of spirituality and their documentation. It can be said that these publications reflect theological trends in the universal Church. Both the documents of the Church and of the popes as well as the events became an inspiration for the authors. Historical, social and even political events were not without their significance and influence. Of particular importance is the development of native Polish theology, having its own specificity and contributing richly to the life of the whole universal Church. We define such a achievement as the "Polish school of spirituality". 